\title{
Editorial: A new source of inspiration
}

'What is the meaning of democracy, freedom, human dignity, standard of living, self realization, fulfilment? Is it a matter of goods, or of people? Of course it is a matter of people. ${ }^{1}$

The economist Ernst Schumacher wrote this back in 1974 in a now famous book, 'Small is Beautiful'. His view was that economists are so focused on the abstract and the analytical that they forget the reality of the people behind the numbers they cite. In a post-Enron world his thoughts seem particularly prescient. Schumacher wasn't being revolutionary in his way of thinking, however. Almost exactly 200 years earlier, Adam Smith published his bestseller, 'The Wealth of Nations'. Although Smith is often seen as the founding father of economics and free-trade thinking, this is too limited a view. Like Schumacher he was concerned with the study of man and also with aesthetics, language, ethics and social laws. In spite of the historical precedent of Smith, however, Schumacher has been a relatively lonely voice in the field of economics. And, we might add, his voice has hardly been heard in the world of marketing.

As a more modern discipline, marketing has sought credibility in adopting the analytical approach of economics and social science. This has been important in two respects. It has helped marketers to understand something of the behaviour of consumers and other audiences, and it has helped the discipline to gain status in the boardroom. Too much reliance on numerical analysis is dangerous, however. Using quantitative studies to define the likely actions of people, the impact of advertising, or the nature of customer loyalty, leads to narrow thinking. Numbers lead to abstraction and planning taking place in a void. They can provide us with an indication of past behaviour and they can even suggest what people might do in the future, but decision-making along these lines leads to marketing campaigns that overstate the importance of products in people's lives, brand valuations that overestimate customer loyalty and product innovations that fail. Researchers might argue that qualitative methods provide the insight into people and temper the tyranny of numbers, but this is still a process concerned with rationality and abstraction. Marketing is often a myopic process that concentrates on a limited vista of measures that define success or failure. We tend to find that marketing justifies itself based on its performance in building awareness, preference and customer loyalty. Yet if we listened to Peter Drucker's point about the raison d'être of organisations - to endeavour consistently to make human progress - we would recognise that marketing has the potential to play a much larger and more valuable role.

\section{A NEW SOURCE OF INSPIRATION}

The power of Enlightenment thinking, of which Smith was such an important part, was that it saw the connection 
between disciplines, ideas and people. Rather than having a narrow focus, marketing too ought to recognise that it is not an isolated element. As one of my fellow editorial board members, Chris Macrae, argues, organisations should not simply think about the numbers but about all the potential linkages in their value chains and winwin situations for all stakeholders. This suggests that marketing must move beyond its quasi-scientific rationality and seek inspiration from other sources as well. For marketing to contribute to human progress it should see organisations not just as economic entities, but as communities with a broader role to play. Business can no longer isolate itself from social responsibilities. People expect organisations to act ethically and to contribute towards sustainable development.

To effect this transition in thinking, marketers, in the way they are trained and practice, need to focus less on analysis and more on people. Equally, this suggests that the humanities should be an important influence. As a conference on the role of humanities argues, a person cannot achieve the insight into this larger role without an understanding of history, philosophy, art and the heritage of knowledge. (The Role of Humanities in the Formation of New European Elites, Venice, 10th-12th September, 2003.)

\section{WHY BUSINESS NEEDS POETS, HISTORIANS AND PHILOSOPHERS}

I recently gave a talk, which was derived very much from personal experience, under this heading at a university in Sweden. While I have a business degree, in the days before marketing was even offered at
British universities I studied English literature and history. Europeans are often intrigued that someone with a humanities background should be working with branding. 'What use is it in business?' they want to know. Yet I find that when I have to confront a branding problem, or when I am writing on brands, my sources of reference and examples are derived primarily from humanistic fields. They provide a context for analysis that is people based. For example, in writing the book, 'Living the Brand', ${ }^{2}$ I was searching for stories to substantiate the dangers of using rational analysis as the sole means of decision making. Whereas I could have chosen a marketing-based example, such as perhaps Absolut Vodka's refusal to abide by the findings of research when it launched in the USA, I found two powerful and profound examples in the German plan for the First World War (which was in existence for 20 years and demonstrated that Germany would surround Paris in six weeks) and in the USA's waging of the Vietnam War (based on long-held and misplaced assumptions). ${ }^{3}$ Both clearly illustrate how an adherence to abstraction can have catastrophic consequences. Equally, in trying to understand the behaviour of people and brands, I found solace not in marketing texts, but in philosophy. In trying to understand what empowerment means, I found the best explanation in Foucault; when confronted with the problem of employees not having a common understanding of vision and value statements, I found answers in Noam Chomsky and Umberto Eco; in looking for a process to define those values and visions I found ideas in Socrates' methods; and in thinking 
about the role of organisations I came to Karl Popper. Nothing, however, gave me greater insight than the existential philosopher, Peter Koestenbaum. His ideas on the nature of leadership and the importance of four dimensions - vision, reality, ethics and courage - which apply very effectively to brands, influenced my thinking not only on the book, but on the way I conduct projects. Now, when I am working with clients on projects involving the rejuvenation or definition of values, Koestenbaum's dimensions are my benchmark.

As this shows, references to the humanities are not only valuable in thinking about bigger questions, such as what is the correct ethical standpoint for a brand, but also as a basis for practical decisions. Take as an example the issue of control. The degree of control a manager exerts over a brand varies. At one extreme the manager can use a tight, rule-led process, such as favoured by the logistics company UPS, or a highly empowered approach, as favoured by the US department store group, Nordstrom. Although we might argue that there is a general trend towards empowerment, as work becomes more knowledge biased, there are still a large number of organisations that favour control. Indeed, much of senior management time is spent trying to control strategy, to ensure it is implemented as planned. As Mintzberg et al suggest, 'a great deal of what has been called strategic planning really amounts to this kind [keeping the organisation on track] of strategic control'. ${ }^{4}$ To some extent, the control a manager exerts is defined by the nature of the operating environment, but it also reflects a philosophical standpoint about trust. If we believe in the ability of the individual to make free and informed choices in line with the organisation's vision and values, we would err on the side of freedom, and in so doing capture the intellectual power of all employees. Alternatively, if we do not trust people to act responsibly, we will tend to favour a rule-based regime that defines how people should behave. According to Brooke Manville and Josiah Ober, ${ }^{5}$ the latter is the norm: 'the entire shape of the modern company reflects a fundamental distrust of its members'. This thought is also endorsed by W. Chan Kim and Rene Mauborgne, ${ }^{6}$ who note that managers tend to assume that employees are always focused on self-interest, and that it is therefore dangerous to give up power to them, and also by research by Chip Heath of Stanford ${ }^{7}$ that shows that managers are not as good at understanding the motivations of employees as they think they are.

We might ask why these misunderstandings occur. In seeking an answer, we can find inspiration in philosophy and literature. In particular, Shakespearean drama demonstrates that the driving force of misunderstanding is the limited perspective of protagonists who are blinded to alternatives by their own assumptions. Macbeth's overweening ambition and Hamlet's thwarted desire prevent them seeing the full implications of their actions. Yet through their soliloquies and the playing out of the drama, these characters learn to understand their limitations. This self-questioning is what makes Hamlet and Macbeth authentically human. The lesson that managers should take out of this is to try to avoid assuming how people will behave, whether they are 
customers or employees, based on personal prejudice. Instead, managers should employ the rhetorical methods that Shakespeare was trained in to understand that truth is not singular and can be seen from many perspectives. $^{8}$

\section{HUMANITIES AND INTEGRATION}

'There is nothing which requires more to be illustrated by philosophy than trade does.'

Samuel Johnson

In my first year as an account executive in an advertising agency, I attended a course of lectures in London. More than 20 years on I remember very little of the lectures, but there was one idea that struck me as important at the time. It was that to be a good student of brands and marketing, you need to be a good student of life. The speaker went on to argue that if you focus too narrowly on the minutiae of a brand, you forget that you are dealing with real people in the real world. This is why I believe the humanities are so important. They remind us that people are not easily measured and categorised and that individuality will confound the best-laid plans. They remind us that we have to try to see people and problems from perspectives other than our own. They remind us of the linkage between things. The humanities do not form an independent area of study devoid from real-world behaviour, any more than marketing is, or should be. The humanities and marketing should contribute to each other, which is the rationale for Bang \& Olufsen's use of theatre to help unlock creativity, ABN
AMRO's commitment to collecting art and the work of LearningLab (www.learninglabdenmark.com) in Denmark on what business can learn from the arts and vice versa.

If we as marketers can learn from the humanities more about ourselves, the people we work with and the customers we serve, we can make better choices and build more effective brands. Using philosophy, art, history and literature as a source of inspiration also enables marketers to create a significant point of difference for their brands. The humanities encourage the individual to pose questions, to seek beauty, to uncover creativity, to recognise emotion and to challenge conventions. These are important attributes when thinking about how to carve out a unique space for a brand in a competitive marketplace. This integration of the humanities will not, however, happen without effort. In a recent article in Philosophy Now on 'Corporate crises: A philosophical challenge', ${ }^{10}$ Alan Malachowski argued that philosophers must leave their ivory towers and contribute to the business problems of the real world. Equally, we should challenge marketers to leave their business towers and engage with the world of philosophy. It would be an interesting experience and also, I think, a valuable one.

\section{Nicholas Ind} Editorial Board

\section{References}

(1) Schumacher, E. (1974) 'Small is Beautiful: A Study of Economics as if People Mattered', Abacus Books, London, UK.

(2) Ind, N. (2001) 'Living the Brand', Kogan Page, London, UK.

(3) Ellsberg, D. (2002) 'Secrets: A Memoir of Vietnam and the Pentagon Papers', Viking Penguin, New York, NY. 
(4) Mintzberg, H., Ahlstrand, B. and Lampel, J. (1998) 'Strategy Safari', Prentice Hall/Financial Times. London, UK, p. 59.

(5) Manville, B. and Ober, J. (2003) 'Beyond Empowerment: Building a company of citizens', Harvard Business Review, Vol. 81, No. 1.

(6) Chan Kim, W. and Mauborgne, R. (2003) 'Fair process: Managing in the knowledge economy', Harvard Business Review, Vol. 81, No. 1.

(7) Morse, G. (2003) 'Why we misread motives', Harvard Business Review, Vol. 81, No. 1.

(8) Bate, J. (1997) 'The Genius of Shakespeare', Picador, London, UK

(9) Quoted in the Introduction to Smith, A. (1776) 'An Inquiry into the Nature and Causes of the Wealth of Nations', Oxford University Press, 1993 edition, Oxford, UK, p. X.

(10) Malachowski, A. (2003) 'Corporate crises: A philosophical challenge', Philosophy Now, Issue 39. 